\title{
Definition of aspirin resistance using whole blood impedance aggregometry in patients undergoing coronary artery surgery: methodological challenges and outcome improvement opportunities
}

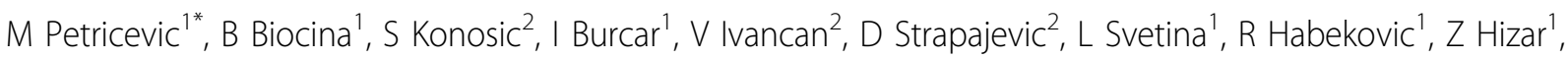 \\ H Gasparovic ${ }^{1}$
}

From 23rd World Congress of the World Society of Cardio-Thoracic Surgeons Split, Croatia. 12-15 September 2013

\section{Background}

A beneficial effect of acetylsalicylic acid (ASA) on vein graft patency has been described, but some patients experience adverse cardiac events despite appropriate ASA treatment. Study aim was to define ASA resistance using Multiple electrode aggregometry (MEA) preoperatively in group of patients undergoing coronary artery bypass grafting (CABG).

\section{Methods}

Prospective observational trial at University Hospital Center Zagreb enrolled 131 patients scheduled for CABG, and divided them into 4 groups with respect to preoperative antiplatelet therapy (APT). Group 1 received $100 \mathrm{mg}$ ASA per day, Group $2100 \mathrm{mg}$ ASA + $75 \mathrm{mg}$ clopidogrel per day, Group $375 \mathrm{mg}$ clopidogrel per day, and Group 4 did not receive any APT. MEA with ASPI test (sensitive to ASA) and ADP test (sensitive to clopidogrel) was performed prior to surgery. In Group 1, patients were characterized as ASA resistant if their ASPI test value exceeded the 75 th percentile distribution.

\section{Results}

Study enrolled 131 patients. Significant differences both in the ASPI $(\mathrm{p}<0.001)$ and the ADP test $(\mathrm{p}=0.038)$ were observed between patients in different APT groups. In Group (1) ASPI test value of 30 AUC presented 75th percentile of distribution, thus indicating ASA resistance. Group 2 patients had slightly lower ADP test values, but no significant difference occurred (mean 60.05 vs. 63.32 AUC, $p=0.469$ ). In Group 1 and 2, significant correlations between the ADP test and both, platelet count $(\mathrm{r}=0.347, \mathrm{p}<0.001)$ and fibrinogen level $(\mathrm{r}=0.364, \mathrm{p}<0.001)$ were observed.

\section{Conclusion}

Association between low response to ASA and postCABG major adverse ischemic events risk increase has been described thus indicating need for ASA resistant patients detection using bedside suitable and drug specific platelet function tests. In patients with preoperative ASPI test exceeding 30 AUC postoperative, ASA dose adjustment or clopidogrel addition according to MEA results should be considered.

\footnotetext{
* Correspondence: petricevic.mate@gmail.com

${ }^{1}$ Department of Cardiac Surgery ; University Hospital Center Zagreb, Zagreb, Croatia

Full list of author information is available at the end of the article
} 


\section{Authors' details}

'Department of Cardiac Surgery ; University Hospital Center Zagreb, Zagreb,

Croatia. ${ }^{2}$ Department of Cardiac Anesthesiology ; University Hospital Center

Zagreb, Zagreb, Croatia.

Published: 11 September 2013

doi:10.1186/1749-8090-8-S1-P122

Cite this article as: Petricevic et al:: Definition of aspirin resistance using

whole blood impedance aggregometry in patients undergoing

coronary artery surgery: methodological challenges and outcome

improvement opportunities. Journal of Cardiothoracic Surgery 20138

(Suppl 1):P122

Submit your next manuscript to BioMed Central and take full advantage of:

- Convenient online submission

- Thorough peer review

- No space constraints or color figure charges

- Immediate publication on acceptance

- Inclusion in PubMed, CAS, Scopus and Google Scholar

- Research which is freely available for redistribution

Submit your manuscript at www.biomedcentral.com/submit 